\title{
Metal Uptake by Plants from Soil Contaminated by Thin-Film Solar Panel Material
}

\author{
Lingcheng Su, Jiajun Chen, Huada Daniel Ruan*, Deborah Jayne Ballantine, Chiuhong Lee \\ Environmental Science Program, Division of Science and Technology, Beijing Normal University-Hong Kong Baptist University \\ United International College, Zhuhai, China \\ Email: ^hruan@uic.edu.hk
}

How to cite this paper: Su, L.C., Chen, J.J., Ruan, H.D., Ballantine, D.J. and Lee, C. (2019) Metal Uptake by Plants from Soil Contaminated by Thin-Film Solar Panel Material. Journal of Environmental Protection, 10, 221-240.

https://doi.org/10.4236/jep.2019.102013

Received: January 10, 2019

Accepted: January 31, 2019

Published: February 3, 2019

Copyright (c) 2019 by author(s) and Scientific Research Publishing Inc. This work is licensed under the Creative Commons Attribution International License (CC BY 4.0).

http://creativecommons.org/licenses/by/4.0/

\begin{abstract}
Various metals, including zinc $(\mathrm{Zn})$, nickel $(\mathrm{Ni})$, aluminum $(\mathrm{Al})$, chromium $(\mathrm{Cr})$, gallium $(\mathrm{Ga})$, lead $(\mathrm{Pb})$, copper $(\mathrm{Cu})$ and indium $(\mathrm{In})$, may be released and cause contamination when scrapped end-of-life (EoL) $\mathrm{Cu}(\mathrm{InGa}) \mathrm{Se}_{2}$ thin-film solar panel (CIGS TFSP) is buried in the soil. In this study, we grew Brassica parachinensis L. H. Bariley ( $\mathrm{Veg}_{\text {Brassica }}$ ) in three different types of soils, namely, a commercial soil, a Mollisol, and an Oxisol, which had been contaminated by CIGS TFSP to various extents. The concentrations of contaminants in these soils were positively correlated with both the amount of CIGS TFSP added and the burial period. Plants grew well in commercial soil and Mollisol, but those in Oxisol showed prominent signs of chlorosis and died after 30 days. The bioaccumulation factor (BF) and concentration of $\mathrm{Zn}$ in $\mathrm{Veg}_{\text {Brassica }}$ grown in commercial soil with $10 \%$ of CIGS TFSP added were 3.61 and $296 \mathrm{mg} / \mathrm{kg}$, respectively, while the BF and concentration of In of $\operatorname{Veg}_{\text {Brassica }}$ grown in Mollisol were 3.80 and $13.72 \mathrm{mg} / \mathrm{kg}$, respectively. The results showed that soils were contaminated by metals released from CIGS TFSP, and different adsorption patterns were observed for $\mathrm{Veg}_{\text {Brassica }}$ depending on which types of metals associated with the soil properties.
\end{abstract}

\section{Keywords}

Bioaccumulation, Contamination, Metal, Plant, Soil, $\mathrm{Cu}(\mathrm{InGa}) \mathrm{Se}_{2}$ Thin-Film Solar Panel (CIGS TFSP)

\section{Introduction}

Because of their persistence in the environment, there is great concern about the effects of heavy metals on human health. Mining and smelting industries, fossil fuel consumption, and the disposal of metal-containing wastes are the main 
anthropogenic sources of metals that accumulate in soils [1] [2]. Metals may enter the food chain when they are taken up by plants [3] [4]. Toxic metals can be accumulated in plants cultivated on metal-contaminated soils in variable quantities via their roots, and then produce further toxic effects in animals and humans through assimilation [2]. Vegetables, especially leafy species, tend to accumulate not only nutrients but also toxic metals in their tissues, with subsequent impacts on food quality and safety. Thus, food consumption was identified as the major pathway of human exposure to heavy metals [5]. Brassica parachinensis L. H. Bariley $\left(\operatorname{Veg}_{\text {Brassica }}\right)$ is a kind of vegetable commonly grown in south China. It has been reported that $\mathrm{Veg}_{\text {Brassica }}$ can uptake heavy metals such as $\mathrm{Cd}$ and $\mathrm{Zn}$ when grown on polluted soil [5]. Therefore, vegetables can be used as a proxy for metal contamination to different levels in agricultural environments [3]. In China, suburban vegetable farms are mainly small-scale family businesses. Organic fertilizers and other agrochemicals are applied generously to soils, and the farms are rarely subject to government food quality checks [6]. In an earlier study, Tan et al. [5] found that the vegetables grown on a farm close to a metal manufacturing factory were heavily polluted by metals. The concentrations of lead $(\mathrm{Pb})$ and copper $(\mathrm{Cu})$ in plants exceeded the thresholds outlined in the National Food Safety Standard of China (GB 2762-2017). Although some metals are essential elements for both plant and human at low concentrations, these metals may be bioaccumulated and their concentrations may be higher than normally acceptable levels and consequently have adverse effects on the ecosystem [6] [7] [8]. Some heavy metals, such as $\mathrm{Cu}$ and zinc $(\mathrm{Zn})$, act as co-factors in various enzymes and are essential in small doses for animal and human. Over-accumulation of these metals in human may result in acute toxicity because of redox cycling and the generation of reactive oxygen species (ROS) that can damage DNA and cause chronic conditions such as Wilson's disease and cirrhosis of the liver [9] [10]. Copper and $\mathrm{Zn}$ in food at high concentrations are therefore of great concern because of their toxicity to human [8] [10] [11]. Over-accumulation of $\mathrm{Zn}$ in human body may cause ataxia and suppress $\mathrm{Cu}$ and iron (Fe) absorption, leading to $\mathrm{Cu}$ and Fe deficiency [9]. Moreover, the consumption of food contaminated by nickel (Ni) can cause respiratory problems, including a type of asthma specific to $\mathrm{Ni}$, decrease lung function, and bronchitis [12].

Some studies have reported that the heavy metals in soils have different availabilities to plants [3]. Contaminants released to soils mainly exist as metal ions at first; these ions are easily acquired by plant roots and raise the amount of metal contaminations in plant tissues. On the other hand, the contaminants that remain trapped in aluminosilicates cannot be absorbed by plant roots, and so the metals in such forms contribute very little to environmental pollution. In general, heavy metals that are originated from anthropogenic sources can be initially converted to ions and can be absorbed by plant roots. Because of bioaccumulation, the concentrations of heavy metals and other toxins in some plants would be higher than those in the natural environment [3]. 
With the rapid development of clean and renewable energy, solar energy devices, including solar thermal heaters, silicon photovoltaic panels, and thin-film photovoltaic panels, are used increasingly and frequently worldwide. Lee [13] reported that $\mathrm{Cu}(\mathrm{InGa}) \mathrm{Se}_{2}$ (CIGS), $\alpha-\mathrm{Si}$, and $\mathrm{CdTe}$ are the three most widely commercialized thin-film solar cells, with energy conversion efficiencies of $22.3 \%, 13.6 \%$, and $22.1 \%$, respectively. As competitors in the field of module efficiency, CIGS and CdTe technologies are accounted for more than $55 \%$ of the global photovoltaic market with the greatest promise for the future [13]. The lifetimes of crystalline silicon and thin-film photovoltaic modules are between 20 and 30 years [14]. The utilization of solar photovoltaic systems has increased rapidly in the recent years, meaning that there may be problems with their disposal in the near future. McDonald and Pearce [15] have predicted that there will be a huge volume of discarded photovoltaic waste to be dealt with after 2030. Because some photovoltaic modules contain heavy metals and organic pollutants, there are concerns about the potential risks from unappropriated treatment and disposal of end-of-life (EoL) solar photovoltaic panels, particularly relating to the release of toxic metals and lethal gases into the soil [16]. It is therefore suggested that a level of administration for EoL photovoltaics may be a financially practical and viable solution for dealing with these issues [17]. In the recent past, numerous privately-owned businesses and research establishments worldwide have carried out lab-scale experiments or pilot industrial procedures to determine the potential for reusing photovoltaic panels including crystalline silicon and thin-film panel [16] [18]. Although there are some techniques for recycling solar photovoltaic panels, the methods are so complex and energy demanding that such EoL treatment is rarely applied in developing countries. For example, in China, to date most EoL thin-film solar panels (TFSP) have not been recycled but rather have been treated as domestic or construction wastes. Some have been directly buried in the soil after disassembly. To promote more efficient use of natural resources and the use of secondary raw materials in the production of photovoltaic panels, a step has been taken towards mindful EoL treatment of photovoltaic modules in the European Directive on Waste Electrical and Electronic Equipment (WEEE; Directive 2012/19/UE of the European Parliament and the Council), which outlines that abandoned photovoltaic modules should be included as residential or special WEEE [19].

To date there have been few studies of plants that have been contaminated from metals released when scrapped CIGS TFSP is buried in the soil. Tammaro [20] reported that the leachates of crystalline silicon photovoltaic panels may contain $\mathrm{Al}, \mathrm{Pb}, \mathrm{Cd}$ and $\mathrm{Sb}$ and those of thin-film photovoltaic panels may contain $\mathrm{Al}, \mathrm{Cr}, \mathrm{Pb}$, Se and $\mathrm{Cd}$. These metals might be released if those panels are disposed of to the soil. Monier and Hestin [21] reported that $\mathrm{Pb}$ and $\mathrm{Cd}$ can be leached from crystalline silicon and thin-film photovoltaic panels. Luo [22] demonstrated that the soils from a previous E-waste incineration site contain high concentrations of $\mathrm{Cd}, \mathrm{Cu}, \mathrm{Pb}$ and $\mathrm{Zn}$. They also found moderately high concentrations of $\mathrm{Cd}$ and $\mathrm{Cu}$ in the soils from adjacent paddy fields and vegeta- 
ble farms, where the concentrations of $\mathrm{Cd}$ and $\mathrm{Pb}$ in the palatable tissues of vegetables surpass the highest level allowed in food in China. In this study we investigated the uptake of metals by Brassica parachinensis L. H. Bariley ( $\operatorname{Veg}_{\text {Brassica }}$ ) grown in a commercial soil, a Mollisol, and an Oxisol that had been contaminated with different amounts of CIGS TFSP. We also investigated the mechanisms that drove the release and transfer of metals from CIGS TFSP to the soil and then their bio-accumulation in plants. The results of this study should provide updated information about the environmental risks associated with the disposal of EoL CIGS TFSP by burial in the soil.

\section{Experimental}

\subsection{Thin-Film Solar Panel and Soil Collection}

We obtained the CIGS type of TFSP from a solar energy company in Zhuhai, China. The collected materials were crushed into pieces of approximately 9.5 $\mathrm{mm}^{\star} 9.5 \mathrm{~mm}$ (length ${ }^{\star}$ width). The crushed pieces were pre-treated by rinsing with distilled deionized (DI) water and then were air-dried. The soil samples for the simulated burial experiments were collected randomly from between 0 and $20 \mathrm{~cm}$ in depth of the soil profiles from two sites in Zhuhai and Shaoguan, both in Guangdong Province, China. The sample from Zhuhai was a neutral Mollisol that represented clean soil while the sample from Shaoguan was an acidic Oxisol that had been contaminated by mineral waste with a low $\mathrm{pH}$. The collected soil samples were air dried and ground to less than $2 \mathrm{~mm}$, and stored in high-density polyethylene (HDPE) buckets. We also used a commercial soil, a type of garden soil used commonly on vegetable farms in China, to simulate the effects of pollution from waste materials in a control environment. All the soil samples were heated at $121^{\circ} \mathrm{C}$ for $24 \mathrm{hrs}$ to eliminate indigenous microorganisms, which could probably result in bio-leaching of metals.

\subsection{Soil Burial Experiment}

Forty-five high-density polyethylene sample pots $(250 \times 150 \times 200 \mathrm{~mm})$ were used for the burial experiment, with fifteen pots for each type of soil and triplicates for each sample of crushed CIGS TFSP. We made two small holes, each with a $5 \mathrm{~mm}$ diameter, in the bottom of each pot to allow water to drain and then placed a pan underneath each pot to collect the drainage water that was returned to the pot once a day. Each pot containing approximately $2 \mathrm{~kg}$ of soil (e.g. Mollisol, Oxisol, and commercial soil) was prepared for the burial experiment. Selected amounts (0 (control, 0\%), 50 (2.5\%), 100 (5\%), 150 (7.5\%), and $200 \mathrm{~g}$ (10\%)) of crushed CIGS TFSP by weight were mixed evenly with different soil samples in the pots. Potted samples were then soaked with $100 \mathrm{~mL}$ of deionized (DI) water once a week and were incubated under natural conditions with a temperature of $25^{\circ} \mathrm{C} \pm 5^{\circ} \mathrm{C}$ for 60 days. For soil sampling at the completion of burial experiment, $1 \mathrm{~g}$ of soil was taken from 5 different points selected randomly in each pot and combined into one sample, air dried, and passed through 
a $0.15 \mathrm{~mm}$ sieve to remove the crushed CIGS TFSP. The pretreated soil sample was then ground with an agate mortar and stored in a polyethylene bag in a desiccator until analysis of metal concentrations.

\subsection{Vegetable Cultivation and Sample Collection}

After 60 days of burial experiment, the soils in the pots to which the crushed

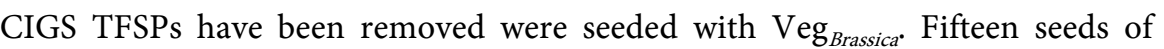
$\mathrm{Veg}_{\text {Brassica }}$ were sowed to each of the pots and ensured evenly distributed. We soaked the soil with $100 \mathrm{~mL}$ of DI water to ensure the seeds germinated and grew. The vegetables were cultivated under natural conditions (spring season, $25^{\circ} \mathrm{C} \pm 5^{\circ} \mathrm{C}$, Zhuhai) for up to 120 days and were soaked daily with $100 \mathrm{~mL}$ of DI water.

After germination, the percentages of successful seeds were recorded, and the plants were thinned out so that five seedlings were remained in each pot. The edible parts (leaves \& stems) of the vegetables were harvested on days 30, 60, 90 and 120 of growth and the lengths of each plant were recorded. The plant samples were rinsed with DI water, and the edible parts were dried at $65^{\circ} \mathrm{C}$ in an oven for $24 \mathrm{hrs}$. The pretreated plant samples were then ground with an agate mortar and passed through a $0.15 \mathrm{~mm}$ sieve and stored in polyethylene bags in a desiccator until further analysis of metal concentrations. The final analytical data of edible materials were taken from the average value of three tests of each replicate.

\subsection{Analytical Methods and Instrumentation}

The metal constituent of CIGS TFSP was analyzed by inductively coupled plasma optical emission spectrometry (ICP-OES, Perkin-Elmer Optima 2100 DV, USA) after strong acid digestion (8 $\mathrm{mL}$ 65\% nitric acid and $2 \mathrm{~mL} \mathrm{40 \%} \mathrm{hydroflu-}$ oric acid) assisted with a microwave digester (Sineo, MDS-10, Shanghai, China).

The soil pH was determined based onsoil:DI water at a weight:volume ratio of 1:2.5. We determined the particle size of soil samples by using the sieve and pipette method [23]. The organic matter (OM) content was estimated after dry combustion at $550^{\circ} \mathrm{C}$ for $5 \mathrm{hrs}$, and the percentage of $\mathrm{OM}$ was calculated using Equation (1) [24] [25] [26]:

$$
O M(\%)=\frac{M_{1}-M_{3}}{M_{1}-M_{2}} \times 100
$$

where $O M$ is the percentage of organic matter in the soil sample, $M_{1}$ is the weight of the crucible and soil sample before combustion, $M_{2}$ is the weight of the crucible, and $M_{3}$ is the weight of the crucible and soil sample after combustion.

The homogenized soil material (approximately $200 \mathrm{mg}$ ) was microwave-digested in $10 \mathrm{~mL}$ of $69 \%$ nitric acid using a Sineo Corporation microwave extraction system. The microwave extraction method USEPA3051A was used according to the Sineo Corporation (Shanghai, China, 2015). After digestion the liquid was 
separated from the solid particles by vacuum filtration through a $0.22 \mu \mathrm{m}$ filter and diluted to $50 \mathrm{~mL}$ [14] [27] [28]. The homogenized plant materials were digested in line with the USEPA3050B. The concentrations of metals ( $\mathrm{Zn}, \mathrm{Ni}$, aluminum ( $\mathrm{Al}$ ), chromium ( $\mathrm{Cr}$ ), gallium $(\mathrm{Ga}), \mathrm{Pb}, \mathrm{Cu}$ and indium (In)) in soil and plant samples after digestions were determined using ICP-OES. Experiments were performed in triplicate. Certified standard reference materials (GBW07605 (GSV-4) for vegetables and GBW07403 (GSS-3) for soils), obtained from the National Institute of Metrology (NIM) China, were used for analysis of 15-samples from each batch according to the guideline in the quality assurance programme. Reagent blanks and analytical triplicates comprised $10 \%$ of the total samples and were used where appropriate to test the accuracy and precision of the analysis. The recovery rates were higher than $90 \%$ for all the metals in the standard reference materials.

\subsection{Calculation of Bioaccumulation Factor (BF)}

We calculated BFsby comparing the metal concentrations in vegetables with those in soils. Using Equation (2), the BF for each metal was calculated from the metal concentrations in the vegetables $(\mathrm{mg} / \mathrm{kg})$ and soil $(\mathrm{mg} / \mathrm{kg})$ :

$$
B F=\frac{c_{\text {vegetable }}}{c_{\text {soil }}}
$$

where $C_{\text {vegetable }}$ is the concentration of metal in the vegetable $(\mathrm{mg} / \mathrm{kg})$ and $C_{\text {soil }}$ is the concentration of metal in the soil $(\mathrm{mg} / \mathrm{kg})$ after 60 days of burial experiment.

\subsection{Statistical Analysis}

Statistical analysis was performed with SPSS (Ver. 22). We used analysis of variance (ANOVA) Duncan's multiple range tests to test the relationships between metal concentrations and different leaching times for various soils. Means were separated using the least significant difference option with $\alpha=0.05$. The correlations between bioaccumulation factor (BF) of $\mathrm{Veg}_{\text {Brassica }}$ and the cultivation period and the percentage of crushed CIGS TFSP added are analyzed using Pearson rank order correlation analysis.

\section{Results and Discussion}

\subsection{Metal Constituent of CIGS TFSP}

The metal constituents in CIGS TFSP are shown in Table 1. Aluminum and Ni were the two most abundant metals with over $57 \%$ of total metal constituent by weight. As expected, $\mathrm{Zn}, \mathrm{Cu}, \mathrm{Ga}$, and In, the important components of CIGS semiconductor layers used for generating electricity, were also present at moderate percentages. The main source of sodium $(\mathrm{Na})$ was glass, while iron $(\mathrm{Fe})$ and vanadium $(\mathrm{V})$ were present in the metal frames used for protection. The remaining metals, detected at low percentages, are added to the CIGS semiconductor layers during manufacturing to optimize the optical and photovoltaic properties, or to prevent from corrosion of the paint coat. 
Table 1. Metal content of CIGS type thin-film solar panel material (by percentage).

\begin{tabular}{cccccccccccc}
\hline Metal & $\mathrm{Al}$ & $\mathrm{Ni}$ & $\mathrm{Zn}$ & $\mathrm{Cu}$ & $\mathrm{Na}$ & $\mathrm{Ga}$ & $\mathrm{V}$ & $\mathrm{In}$ & $\mathrm{Fe}$ & $\mathrm{Pb}$ & Others \\
\hline$(\%)$ & 38.25 & 19.52 & 12.34 & 9.20 & 5.09 & 4.79 & 4.73 & 2.99 & 1.73 & 0.56 & 0.79 \\
\hline
\end{tabular}

\subsection{Soil Properties}

As shown in Table 2, the commercial soil, with a neutral $\mathrm{pH}$ of 7.2 and a high organic matter percentage $(\mathrm{OM}$ commercial $=9 \%)$, provides the most suitable soil conditions for plant cultivation. The Mollisol that has a lower $\mathrm{pH}$ value of 5.8 and a higher percentage of clay (Clay Mollisol $=56 \%$ ) than the commercial soil represents the natural conditions for plant cultivation in southern China. In the Oxisol, the $\mathrm{pH}$ is the lowest (3.9), and the initial heavy metal concentrations are high, since the Oxisol has been heavily polluted by mining wastewater and was used to represent a contaminated environment (Table 3).

As shown in Table 3, the metal concentrations in commercial soil, Mollisol, and Oxisol increased as the additions of CIGS TFSP increased. The variability in metal concentrations in these soils highlights the varying abilities of different soils to mobilize pollutants from the buried CIGS TFSP. Overall, the commercial soil showed the best ability to promote $\mathrm{Ni}$ leaching, and the Mollisol to $\mathrm{Zn}$ leaching. The Oxisolca used the greatest amount of Cumobilization over 60 days of burial, but it had the highest background concentration of metals. We found that the metals in CIGS TFSP could be released when the protective layers were broken. Metals released from CIGS TFSP resulted in medium to heavy soil contamination and the amounts of metals released varied according to the properties of soils and the amounts of CIGS TFSP added. Studies have shown that heavy metals released into soils can cause serious illnesses in human, as a consequence of consuming vegetables grown on heavy metal contaminated soils [9] [29] [30] [31] [32].

\subsection{Metal Uptake during Vegetable Cultivation}

The vegetables grew in the commercial soil and the neutral Mollisol for 120 days, but those in the Oxisol germinated and then died within 30 days. There were no significant differences in either percentages of vegetables that germinated or the lengths of the vegetables $(10-25 \mathrm{~cm})$ among the treatments for the same type of soil.

\section{Commercial soil}

The concentrations of major metals in vegetables cultivated in the commercial soil with different amounts of CIGS TFSP added are plotted in Figure 1. Over the entire experimental period, the metal concentrations showed a tendency to increase in the edible vegetable tissues. As the amounts of CIGS TFSP added increased, the concentrations of $\mathrm{Zn}, \mathrm{Ni}$ and In in the commercial soil also increased over the first 30 days of experiment (Table 3). The ongoing release of $\mathrm{Zn}, \mathrm{Ni}$ and In from CIGS TFSP over 120 days of cultivation may suggest that the thin-film protective coating layer was corroded, thus accelerating the release of 
Table 2. Properties of three soils used in this study.

\begin{tabular}{cccccc}
\hline & $\mathrm{pH}$ & $\begin{array}{c}\text { Organic } \\
\text { matter }\end{array}$ & $\begin{array}{c}\text { Clay } \\
(<2 \mu \mathrm{m})\end{array}$ & $\begin{array}{c}\text { Silt } \\
(2-20 \mu \mathrm{m})\end{array}$ & $\begin{array}{c}\text { Sand } \\
(>20 \mu \mathrm{m})\end{array}$ \\
\hline Commercial soil & 7.2 & $9 \%$ & $9 \%$ & $34 \%$ & $48 \%$ \\
Mollisol & 5.8 & $5 \%$ & $56 \%$ & $9 \%$ & $30 \%$ \\
Oxisol & 3.9 & $8 \%$ & $42 \%$ & $3 \%$ & $47 \%$ \\
\hline
\end{tabular}

Table 3. Metal concentrations in CIGS TFSP-contaminated soils after incubation for 60 days and before vegetable cultivation $(\mathrm{mg} / \mathrm{kg})$.

\begin{tabular}{|c|c|c|c|c|c|}
\hline \multirow{2}{*}{$\begin{array}{c}\text { Soil type } \\
\text { Commercial } \\
\text { soil }\end{array}$} & \multicolumn{5}{|c|}{ Amount of CIGS TFSP added (\%) } \\
\hline & $0 \%$ & $2.5 \%$ & $5 \%$ & $7.5 \%$ & $10 \%$ \\
\hline $\mathrm{Zn}$ & $40 \pm 0.80^{\mathrm{d}}$ & $40.24 \pm 3.63^{\mathrm{d}}$ & $58.29 \pm 2.19^{c}$ & $69.74 \pm 6.49^{b}$ & $82.03 \pm 3.10^{\mathrm{a}}$ \\
\hline $\mathrm{Ni}$ & $10.80 \pm 0.31^{\mathrm{e}}$ & $17.80 \pm 0.54^{\mathrm{d}}$ & $42.30 \pm 1.92^{\mathrm{c}}$ & $89.00 \pm 7.04^{\mathrm{b}}$ & $137.00 \pm 10.85^{\mathrm{a}}$ \\
\hline $\mathrm{Al}$ & $91.00 \pm 2.47^{\mathrm{d}}$ & $141.34 \pm 11.74^{\mathrm{bc}}$ & $164.41 \pm 8.24^{\mathrm{b}}$ & $264.74 \pm 22.32^{\mathrm{a}}$ & $276.09 \pm 21.75^{\mathrm{a}}$ \\
\hline $\mathrm{Cr}$ & $7.04 \pm 0.17^{\mathrm{b}}$ & $8.18 \pm 0.68^{\mathrm{a}}$ & $8.04 \pm 0.21^{\mathrm{a}}$ & $8.65 \pm 0.45^{\mathrm{a}}$ & $8.37 \pm 0.133^{\mathrm{a}}$ \\
\hline $\mathrm{Ga}$ & $3.15 \pm 0.27^{c}$ & $3.95 \pm 0.35^{c}$ & $4.56 \pm 0.43^{b c}$ & $5.92 \pm 0.11^{\mathrm{a}}$ & $5.15 \pm 0.17^{b}$ \\
\hline $\mathrm{Pb}$ & $4.03 \pm 0.36^{\mathrm{b}}$ & $4.82 \pm 0.33^{\mathrm{b}}$ & $6.81 \pm 0.51^{\mathrm{a}}$ & $6.91 \pm 0.63^{\mathrm{a}}$ & $4.22 \pm 0.12^{\mathrm{b}}$ \\
\hline $\mathrm{Cu}$ & $12.05 \pm 0.64^{\mathrm{c}}$ & $12.28 \pm 0.81^{\mathrm{c}}$ & $35.65 \pm 1.79^{\mathrm{b}}$ & $36.76 \pm 2.13^{\mathrm{ab}}$ & $38.95 \pm 0.89^{\mathrm{a}}$ \\
\hline In & $6.60 \pm 0.25^{\mathrm{e}}$ & $8.50 \pm 0.69^{d}$ & $10.30 \pm 0.29^{c}$ & $11.20 \pm 0.41^{\mathrm{b}}$ & $16.50 \pm 0.38^{\mathrm{a}}$ \\
\hline Mollisol & $0 \%$ & $2.5 \%$ & $5 \%$ & $7.5 \%$ & $10 \%$ \\
\hline $\mathrm{Zn}$ & $28.15 \pm 1.68^{\mathrm{e}}$ & $44.16 \pm 3.66^{\mathrm{d}}$ & $69.44 \pm 6.18^{c}$ & $90.55 \pm 1.13^{\mathrm{b}}$ & $131.65 \pm 4.82^{\mathrm{a}}$ \\
\hline $\mathrm{Ni}$ & $2.80 \pm 0.26^{\mathrm{e}}$ & $5.05 \pm 0.07^{\mathrm{d}}$ & $7.45 \pm 0.46^{\mathrm{c}}$ & $12.05 \pm 0.2^{\mathrm{b}}$ & $13.56 \pm 0.36^{\mathrm{a}}$ \\
\hline $\mathrm{Al}$ & $137.09 \pm 4.40^{\mathrm{d}}$ & $203.63 \pm 4.01^{c}$ & $218.60 \pm 8.77^{\mathrm{b}}$ & $293.13 \pm 9.82^{\mathrm{a}}$ & $281.14 \pm 9.83^{\mathrm{a}}$ \\
\hline $\mathrm{Cr}$ & $13.45+0.79^{c}$ & $14.01 \pm 0.78^{\mathrm{bc}}$ & $15.67 \pm 1.11^{\mathrm{abc}}$ & $16.09 \pm 0.89^{\mathrm{ab}}$ & $16.99+1.08^{\mathrm{a}}$ \\
\hline $\mathrm{Ga}$ & $9.50 \pm 0.95^{\mathrm{b}}$ & $10.025 \pm 0.87^{\mathrm{b}}$ & $12.34 \pm 0.68^{\mathrm{a}}$ & $13.30 \pm 1.14^{\mathrm{a}}$ & $13.99 \pm 0.11^{\mathrm{a}}$ \\
\hline $\mathrm{Pb}$ & $27.10 \pm 2.60^{\mathrm{b}}$ & $26.05 \pm 0.44^{\mathrm{b}}$ & $29.70 \pm 0.27^{\mathrm{ab}}$ & $31.76 \pm 2.24^{\mathrm{a}}$ & $32.71 \pm 1.67^{\mathrm{a}}$ \\
\hline $\mathrm{Cu}$ & $18.80 \pm 0.48^{\mathrm{e}}$ & $27.70 \pm 1.37^{\mathrm{d}}$ & $30.81 \pm 1.28^{\mathrm{bc}}$ & $31.83 \pm 1.66^{\mathrm{b}}$ & $37.74 \pm 1.06^{\mathrm{a}}$ \\
\hline In & $1.41 \pm 0.13^{\mathrm{e}}$ & $2.64 \pm 0.06^{c}$ & $2.91 \pm 0.08^{\mathrm{b}}$ & $2.49 \pm 0.2^{\mathrm{d}}$ & $3.61 \pm 0.29^{\mathrm{a}}$ \\
\hline Oxisol & $0 \%$ & $2.5 \%$ & $5 \%$ & $7.5 \%$ & $10 \%$ \\
\hline $\mathrm{Zn}$ & $95.50 \pm 4.17^{\mathrm{a}}$ & $56.11 \pm 3.73^{\mathrm{d}}$ & $74.01 \pm 6.12^{\mathrm{c}}$ & $83.65 \pm 4.2^{\mathrm{b}}$ & $91.56 \pm 9.15^{\mathrm{ab}}$ \\
\hline $\mathrm{Ni}$ & $20.42 \pm 0.48^{c}$ & $20.10 \pm 0.69^{c}$ & $30.53 \pm 2.45^{\mathrm{b}}$ & $45.34 \pm 3.33^{\mathrm{a}}$ & $43.74 \pm 3.38^{\mathrm{a}}$ \\
\hline $\mathrm{Al}$ & $156.70 \pm 6.48^{c}$ & $167.80 \pm 1.75^{\mathrm{bc}}$ & $170.80 \pm 14.07^{\mathrm{bc}}$ & $184.10 \pm 15.14^{\mathrm{b}}$ & $234.70 \pm 18.95^{\mathrm{a}}$ \\
\hline $\mathrm{Cr}$ & $18.53 \pm 1.53^{\mathrm{a}}$ & $16.96 \pm 0.016^{c}$ & $17.05 \pm 0.92^{\mathrm{bc}}$ & $18.50 \pm 0.29^{\mathrm{a}}$ & $18.40 \pm 1.47^{\mathrm{ab}}$ \\
\hline $\mathrm{Ga}$ & $2.05 \pm 0.03^{\mathrm{c}}$ & $1.93 \pm 0.02^{c}$ & $3.21 \pm 0.08^{\mathrm{b}}$ & $3.29 \pm 0.10^{\mathrm{b}}$ & $12.39 \pm 1.06^{\mathrm{a}}$ \\
\hline $\mathrm{Pb}$ & $193.60 \pm 2.15^{\mathrm{a}}$ & $162.55 \pm 3.10^{c}$ & $158.93 \pm 10.76^{c}$ & $157.29 \pm 13.86^{\mathrm{c}}$ & $171.97 \pm 15.35^{\mathrm{b}}$ \\
\hline $\mathrm{Cu}$ & $294.30 \pm 19.10^{c}$ & $279.63 \pm 26.72^{c}$ & $348.36 \pm 7.08^{\mathrm{b}}$ & $370.63 \pm 32.72^{\mathrm{a}}$ & $379.79 \pm 1.23^{\mathrm{a}}$ \\
\hline In & $5.28 \pm 0.50^{\mathrm{bc}}$ & $5.20 \pm 0.13^{c}$ & $5.67 \pm 0.56^{\mathrm{b}}$ & $9.84 \pm 0.33^{\mathrm{a}}$ & $9.99 \pm 0.08^{\mathrm{a}}$ \\
\hline
\end{tabular}

The value shown is the mean \pm S.D. The different small letters indicate statistical significance at $p<0.05$ with the Duncan's multiple range test $(n=3)$. 


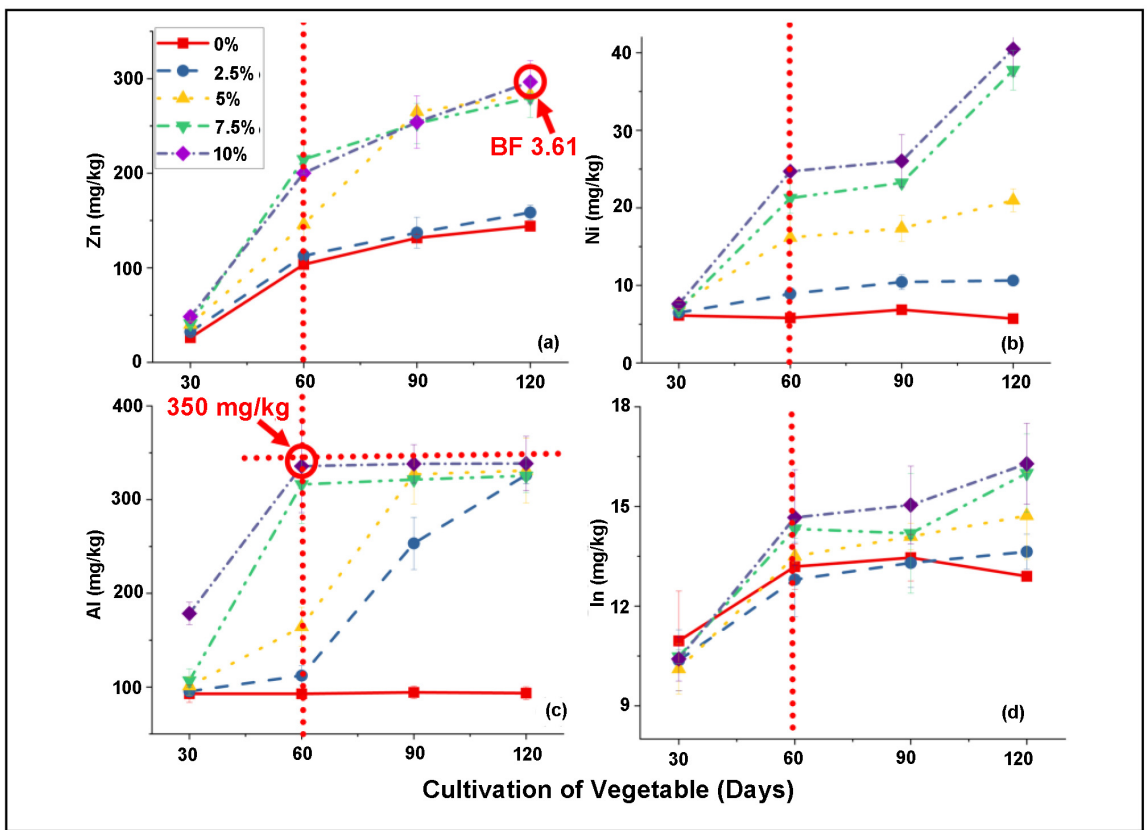

Figure 1. Metal concentrations in vegetables cultivated in commercial soil. Labels in (a) indicate the amounts of CIGS TFSP added.

those metals. As shown in Figure 1, the $\mathrm{Al}$ concentrations followed a different pattern than the $\mathrm{Zn}, \mathrm{Ni}$ and in concentrations, and reached a maximum value $(350 \mathrm{mg} / \mathrm{kg}$ ) much earlier than other metals (Figure 1(c)). The Al concentration in commercial soil treated with $7.5 \%$ and $10 \%$ of CIGS TFSP reached $350 \mathrm{mg} / \mathrm{kg}$ at 60 days of cultivation, while the $\mathrm{Al}$ concentrations in this soil treated with $5 \%$ and $2.5 \%$ of CIGS TFSP reached 338 and $325 \mathrm{mg} / \mathrm{kg}$ in 90 and 120 days of cultivation, respectively (Figure $1(\mathrm{c})$ ). The increases in concentrations of metals in vegetable tissues reflect the amounts of CIGS TFSP added to soils over the cultivation period; they also showed that metals in CIGS TFSP were transferred into vegetable tissues via the soil.

The metal BFs of $\operatorname{Veg}_{\text {Brassica }}$ cultivated in the commercial soil (after 60 days of burial experiment) on days 30,60, 90 and 120 of growth, which were treated with $0 \%$ (Blank), $2.5 \%, 5 \%, 7.5 \%$, and $10 \%$ of CIGS TFSP respectively, are shown in Table 4. These values clearly show that the plants can accumulate different amounts of metals in their edible tissues, and the differences in accumulation reflect the selectivity of plants for the uptake and translocation of different metals. In general, the values of $\mathrm{BF}$ increased as the plant cultivation time increased but decreased or remained slight variation as the amounts of CIGS TFSP added increased. The BFs of $\mathrm{Ni}, \mathrm{Ga}$ and In of $\mathrm{Veg}_{\text {Brassica }}$ grown in commercial soil showed negative correlations with the amounts of CIGS TFSP added to soil $(p<0.05$ or $<0.01$ ), indicating that $\mathrm{BF}$ decreased with an increase in the amount of CIGS TFSP added. This illustrated that these three metals could be absorbed by VegBrassica but high background concentrations of metals in soil could resulted in low $\mathrm{BF}$ values after calculation even if the total amounts of metals were increased in $\mathrm{Veg}_{\text {Brassica }}$ There was a positive relationship between cultivation period and the 
Table 4. Metal BFs of vegetables cultivated in commercial soil contaminated by CIGS TFSP.

\begin{tabular}{|c|c|c|c|c|c|c|}
\hline \multirow{2}{*}{$\begin{array}{c}\text { Sampling day } \\
\mathrm{Zn}\end{array}$} & \multicolumn{5}{|c|}{ Amount of CIGSTFSP added (\%) } & \multirow{2}{*}{ Correlations $(r)$} \\
\hline & $0 \%$ & $2.5 \%$ & $5 \%$ & $7.5 \%$ & $10 \%$ & \\
\hline $30^{\text {th }}$ & 0.65 & 0.80 & 0.69 & 0.59 & 0.59 & -0.599 \\
\hline $60^{\text {th }}$ & 2.59 & 2.80 & 2.50 & 3.08 & 2.44 & -0.012 \\
\hline $90^{\text {th }}$ & 3.29 & 3.41 & 4.54 & 3.62 & 3.10 & -0.048 \\
\hline $120^{\text {th }}$ & 3.60 & 3.94 & 4.85 & 4.01 & 3.61 & 0.028 \\
\hline Correlations $(r)$ & $0.931^{\star}$ & $0.943^{*}$ & $0.966^{*}$ & $0.907^{\star}$ & $0.951^{*}$ & - \\
\hline $\mathrm{Ni}$ & $0 \%$ & $2.5 \%$ & $5 \%$ & $7.5 \%$ & $10 \%$ & Correlations $(r)$ \\
\hline $30^{\text {th }}$ & 0.57 & 0.36 & 0.18 & 0.08 & 0.06 & $-0.957^{\star *}$ \\
\hline $60^{\text {th }}$ & 0.54 & 0.50 & 0.38 & 0.24 & 0.18 & $-0.986^{* *}$ \\
\hline $90^{\text {th }}$ & 0.64 & 0.59 & 0.41 & 0.26 & 0.19 & $-0.985^{\star *}$ \\
\hline $120^{\text {th }}$ & 0.53 & 0.60 & 0.50 & 0.42 & 0.30 & $-0.881^{\star}$ \\
\hline Correlations $(r)$ & -0.052 & $0.941^{\star}$ & $0.947^{\star}$ & $0.966^{\star}$ & $0.961^{\star}$ & - \\
\hline $\mathrm{Al}$ & $0 \%$ & $2.5 \%$ & $5 \%$ & $7.5 \%$ & $10 \%$ & Correlations $(r)$ \\
\hline $30^{\text {th }}$ & 1.02 & 0.68 & 0.62 & 0.40 & 0.65 & -0.724 \\
\hline $60^{\text {th }}$ & 1.02 & 0.79 & 1.00 & 1.19 & 1.22 & 0.732 \\
\hline $90^{\text {th }}$ & 1.04 & 1.79 & 1.99 & 1.21 & 1.22 & -0.084 \\
\hline $120^{\text {th }}$ & 1.03 & 2.31 & 2.01 & 1.23 & 1.23 & -0.191 \\
\hline Correlations (r) & 0.674 & $0.963^{*}$ & $0.946^{*}$ & 0.799 & 0.783 & - \\
\hline $\mathrm{Cr}$ & $0 \%$ & $2.5 \%$ & $5 \%$ & $7.5 \%$ & $10 \%$ & Correlations (r) \\
\hline $30^{\text {th }}$ & 0.80 & 0.70 & 0.70 & 0.64 & 0.73 & -0.544 \\
\hline $60^{\text {th }}$ & 0.96 & 0.86 & 0.96 & 0.89 & 1.07 & 0.488 \\
\hline $90^{\text {th }}$ & 1.02 & 0.85 & 0.92 & 0.85 & 0.92 & -0.453 \\
\hline $120^{\text {th }}$ & 0.91 & 0.78 & 0.80 & 0.77 & 0.81 & -0.593 \\
\hline Correlations $(r)$ & 0.540 & 0.401 & 0.284 & 0.410 & 0.079 & - \\
\hline $\mathrm{Ga}$ & $0 \%$ & $2.5 \%$ & $5 \%$ & $7.5 \%$ & $10 \%$ & Correlations $(r)$ \\
\hline $30^{\text {th }}$ & 2.25 & 1.82 & 1.58 & 1.29 & 1.39 & $-0.927^{\star}$ \\
\hline $60^{\text {th }}$ & 2.34 & 1.89 & 1.62 & 1.28 & 1.46 & $-0.906^{\star}$ \\
\hline $90^{\text {th }}$ & 2.44 & 1.94 & 1.71 & 1.32 & 1.50 & $-0.909^{*}$ \\
\hline $120^{\text {th }}$ & 2.44 & 1.85 & 1.64 & 1.23 & 1.45 & $-0.889^{*}$ \\
\hline Correlations $(r)$ & $0.946^{*}$ & 0.348 & 0.641 & -0.483 & 0.625 & - \\
\hline $\mathrm{Pb}$ & $0 \%$ & $2.5 \%$ & $5 \%$ & $7.5 \%$ & $10 \%$ & Correlations $(r)$ \\
\hline $30^{\text {th }}$ & 0.18 & 0.16 & 0.15 & 0.15 & 0.41 & 0.633 \\
\hline $60^{\text {th }}$ & 0.35 & 0.25 & 0.22 & 0.19 & 0.29 & -0.456 \\
\hline $90^{\text {th }}$ & 0.38 & 0.32 & 0.22 & 0.24 & 0.35 & -0.319 \\
\hline $120^{\text {th }}$ & 0.49 & 0.53 & 0.36 & 0.38 & 0.66 & 0.247 \\
\hline Correlations $(r)$ & $0.966^{*}$ & $0.967^{\star}$ & $0.923^{*}$ & $0.952^{\star}$ & 0.643 & - \\
\hline
\end{tabular}




\section{Continued}

\begin{tabular}{|c|c|c|c|c|c|c|}
\hline $\mathrm{Cu}$ & $0 \%$ & $2.5 \%$ & $5 \%$ & $7.5 \%$ & $10 \%$ & Correlations $(r)$ \\
\hline $30^{t h}$ & 0.65 & 0.64 & 0.21 & 0.21 & 0.20 & $-0.876^{*}$ \\
\hline $60^{t h}$ & 1.01 & 1.01 & 0.40 & 0.42 & 0.45 & $-0.84^{*}$ \\
\hline $90^{t h}$ & 1.15 & 1.33 & 0.43 & 0.48 & 0.50 & -0.796 \\
\hline $120^{t h}$ & 0.97 & 1.07 & 0.37 & 0.45 & 0.39 & $-0.826^{*}$ \\
\hline Correlations $(r)$ & 0.672 & 0.73 & 0.671 & 0.822 & 0.61 & - \\
\hline In & $0 \%$ & $2.5 \%$ & $5 \%$ & $7.5 \%$ & $10 \%$ & Correlations $(r)$ \\
\hline $30^{\text {th }}$ & 1.66 & 1.22 & 0.98 & 0.94 & 0.63 & $-0.965^{\star *}$ \\
\hline $60^{t h}$ & 1.95 & 1.51 & 1.31 & 1.28 & 0.89 & $-0.962^{\star *}$ \\
\hline $90^{t h}$ & 2.00 & 1.56 & 1.37 & 1.27 & 0.91 & $-0.976^{\star *}$ \\
\hline $120^{t h}$ & 2.04 & 1.60 & 1.43 & 1.43 & 0.99 & $-0.950^{\star \star}$ \\
\hline Correlations $(r)$ & 0.892 & 0.892 & $0.905^{*}$ & $0.912^{*}$ & $0.910^{*}$ & - \\
\hline
\end{tabular}

${ }^{\star} p<0.05 ;{ }^{* *} p<0.01$.

$\mathrm{BF}$ values of some metals (e.g. $\mathrm{BF}_{\mathrm{Zn}-10 \%}: \mathrm{r}=0.951, p<0.05 ; \mathrm{BF}_{\mathrm{Ni}-10 \%}: \mathrm{r}=0.961, p<$ $\left.0.05 ; \mathrm{BF}_{\mathrm{In}-10 \%}: \mathrm{r}=0.910, p<0.05\right)$, indicating that the $\mathrm{BF}_{\mathrm{Zn}}, \mathrm{BF}_{\mathrm{Ni}}$ and $\mathrm{BF}_{\mathrm{In}}$ of $\mathrm{Veg}-$ Brassica cultivated in the commercial soil after $10 \%$ of CIGS TSFP was added increased with the cultivation period. This suggested that a longer cultivation period could result in higher bioaccumulation of metals $\mathrm{Zn}, \mathrm{Ni}$ and In. The BF values of other metals might not reveal the highest ones associated with the largest amounts of CIGS TSFP added, but they show similar trends in other treatments with various amounts of CIGS TSFP added. The increases in BF with cultivation time may reflect the transfer of metals from soils via a root system to plant tissues. The lower BF values with time may partly reflect the increases in background metal concentrations in the soil (after 60 days of burial experiment); alternatively, they may reflect an exclusion strategy by metal immobilization in roots or a pending equilibrium because of saturation of the adsorbed metals [33].

The concentrations of $\mathrm{Ga}, \mathrm{Zn}$, In and $\mathrm{Al}$ were usually higher in plants than in the commercial soil (after 60 days of burial experiment), indicating high accumulation rates of these metals especially in plant roots, while the concentrations of $\mathrm{Ni}, \mathrm{Cr}, \mathrm{Cu}$ and $\mathrm{Pb}$ were usually lower in the plants than in the commercial soil. This could indicate the low affinity to adsorption by plant roots, or immobilization of these metals, or less competitive of $\mathrm{Ni}, \mathrm{Cr}, \mathrm{Cu}$ and $\mathrm{Pb}$ compared to $\mathrm{Ga}, \mathrm{Zn}$, In and Al. Even among the high accumulation metals, $\mathrm{Zn}$ accumulation was significantly higher $(p<0.05)$ than were $\mathrm{Ga}$, In and Al. Zinc is an essential element for plant growth. With the BF value of 3.61 (when the concentration in soil treated with $10 \%$ of CIGS TFSP is $82 \mathrm{mg} / \mathrm{kg}$ (Table 3 ) and the concentration in the $\mathrm{Veg}_{\text {Brassica }}$ is $296 \mathrm{mg} / \mathrm{kg}$ (Figure 1)), $\mathrm{Zn}$ has a stronger bioaccumulation ability than other metals. The BF values of $\mathrm{Zn}$ were almost the same for all the treatments after different amounts of CIGS TFSP were added, but the amount of 
uptake changed significantly with the period of cultivation $(p<0.05)$. The amount of $\mathrm{Zn}$ uptake increased as both the cultivation period and the amounts of CIGS TFSP increased. The reason for very similar BF values obtained was because the $\mathrm{Zn}$ concentrations performed $\mathrm{Al}$ most identical increasing trends in both plants and soils. This indicates that $\mathrm{Veg}_{\text {Brassica }}$ was able to tolerate a high concentration of $\mathrm{Zn}$ in the soil and to accumulate $\mathrm{Zn}$ in its tissues. Han et al. [34] reported that some Cruciferae plants, such as Thlaspi caeralescens, had a very strong ability to accumulate $\mathrm{Zn}$ in their tissues, and some hyper-accumulator plants, such as Brassica juncea, Brassica napus and Brassica rapa, could absorb and accumulate $\mathrm{Zn}$ in their leaves and roots [34]. After 120 days of cultivation for other metals, the BFs for Ga, and In were 2.44, and 2.04 for plants grown in blank commercial soil samples, but were 1.45 , and 0.99 , respectively, in the commercial soil samples treated with $10 \%$ of CIGS TFSP (Table 4). Based on the discussion earlier, the BF of $\mathrm{Zn}$ remained almost constant in all the commercial soil samples treated between none and $10 \%$ of CIGS TFSP added, indicating that for all the metals, $\mathrm{Veg}_{\text {Brassica }}$ grown in the commercial soilaccumulated the higher amount of $\mathrm{Zn}$. Although BF of Ga was 2.44 in the blank but was 1.45 in the $10 \%$ treatment, it performed the second highest BF in the commercial soil (Table 4). The BF of In changed from 2.04 in the blank treatment to approximately 0.99 (after 10\% CIGS TFSP was added), indicating that there might be a state of equilibrium $(\sim 1.00)$ of In uptake in plants (Table 4). It was noted that the uptake and accumulation of In in $\mathrm{Veg}_{\text {Brassica }}$ increased as both the cultivation time and the concentrations of In in the commercial soil increased. The In concentrations in the vegetable tissues and the soils without CIGS TFSP added were 13.5 and $6.6 \mathrm{mg} / \mathrm{kg}$, respectively, while the In concentrations in plant tissues and commercial soils treated with $10 \%$ of CIGS TFSP were 16.3 and $16.5 \mathrm{mg} / \mathrm{kg}$, respectively (Figure 1 (d); Table 3). It was clear that the In concentration was higher in vegetable tissues grown in soil treated with $10 \%$ of CIGS TFSP than in the soil with no CIGS TFSP added (Figure 1(d)), but the BF was lower in contrast (Table 4). This dynamic equilibrium was probably influenced by In interactions within the rhizosphere, such as adsorption and desorption of metals in the soil, and the selectivity and affinity of plant root systems to metals.

\section{Mollisol}

As shown in Figure 2, the main metals accumulated in vegetables grown in Mollisol were $\mathrm{Zn}, \mathrm{Ni}, \mathrm{Al}$ and In. In Mollisol treated with different amounts of CIGS TFSP, all the metal concentrations showed a tendency to increase in all the vegetable samples over the entire experiment period. These patterns are similar to those for the commercial soil. The $\mathrm{Zn}$ concentrations in vegetables grown in the Mollisol continued to increase over the 120-day cultivation period, but were much lower than those in the vegetables grown in the commercial soil.

The metal BFs of $\mathrm{Veg}_{\text {Brassica }}$ cultivated in the Mollisol (after 60 days of burial experiment) at days $30,60,90$, and 120 , treated with $0 \%$ (Blank), $2.5 \%, 5 \%, 7.5 \%$, 


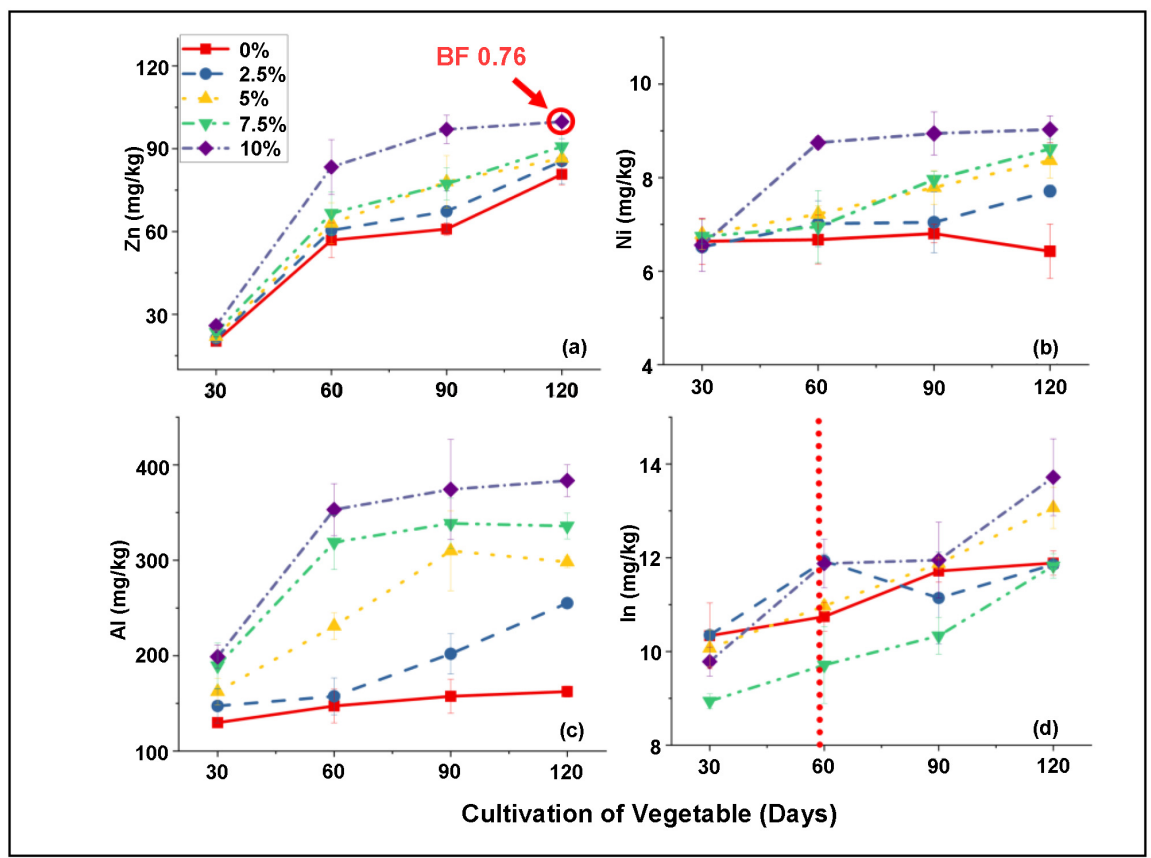

Figure 2. Metal concentrations in vegetables cultivated in the Mollisol. Labels in (a) indicate the amounts of TFSP added.

and $10 \%$ of CIGS TFSP, are shown in Table 5 . The BFs of $\mathrm{Zn}, \mathrm{Ni}$ and Ga of VegBrassica grown in Mollisol showed a close negative correlation with the amount of CIGS TFSP added $(p<0.01)$, indicating that BF decreased with an increase in the amount of CIGS TFSP added. As discussed earlier, this is again due to a high background concentration of metal in the soil. There was a strong positive relationship between cultivation period and the BFs of some metals (e.g. $\mathrm{BF}_{\mathrm{Cr}-10 \%}: \mathrm{r}=$ $0.951, p<0.05 ; \mathrm{BF}_{\mathrm{Pb}-10 \%}: \mathrm{r}=0.969, p<0.05 ; \mathrm{BF}_{\mathrm{Cu}-10 \%}: \mathrm{r}=0.986, p<0.01 ; \mathrm{BF}_{\mathrm{In}-10 \%}: \mathrm{r}$ $=0.953, p<0.05)$, indicating that the $\mathrm{BF}_{\mathrm{Cr}}, \mathrm{BF}_{\mathrm{Pb}}, \mathrm{BF}_{\mathrm{Cu}}$, and $\mathrm{BF}_{\mathrm{In}}$ of $\mathrm{Veg}_{\text {Brassica }}$ cultivated in Mollisol with $10 \%$ of CIGS TSFP added increased with cultivation period. This suggested that longer cultivation period could result in higher bioaccumulation of $\mathrm{Cr}, \mathrm{Pb}, \mathrm{Cu}$ and In. These BFs of metals clearly show that bio-accumulation varied in plant samples, and the metal uptake and storage in plants increased as the cultivation period increased but decreased as the additions of CIGS TFSP increased. For instance, the BF of In was 8.43 with no CIGS TFSP added but was 3.80 when treated with $10 \%$ of CIGS TFSP after 120 days of cultivation while, in general, the In BFs were higher after 120 days than after 30 days of cultivation for all treatments. Similar trends were also observed for most of other metals (Table 5).

After 120 days of cultivation, the $\mathrm{BF}$ of $\mathrm{Zn}$ was 0.76 in plants grown in the Mollisol treated with $10 \%$ of CIGS TFSP (Table 5), while it was 3.61 for the plants cultivated in commercial soil treated with $10 \%$ of CIGS TFSP (Table 4), which indicated that the plants grown in the commercial soil could accumulate more $\mathrm{Zn}$ than those grown in the Mollisol. Meanwhile, the $\mathrm{Zn}$ concentrations in the commercial soil and the Mollisol treated with $10 \%$ of CIGS TFSP were 82.03 
Table 5. Metal BFs of vegetables cultivated in the Mollisol contaminated by CIGS TFSP.

\begin{tabular}{|c|c|c|c|c|c|c|}
\hline \multirow{2}{*}{$\begin{array}{c}\text { Sampling day } \\
\mathrm{Zn}\end{array}$} & \multicolumn{5}{|c|}{ Amount of CIGS TFSP added (\%) } & \multirow[b]{2}{*}{ Correlations $(r)$} \\
\hline & $0 \%$ & $2.5 \%$ & $5 \%$ & $7.5 \%$ & $10 \%$ & \\
\hline $30^{\text {th }}$ & 0.72 & 0.48 & 0.32 & 0.26 & 0.20 & $-0.953^{* *}$ \\
\hline $60^{\text {th }}$ & 2.02 & 1.37 & 0.91 & 0.74 & 0.63 & $-0.946^{\star *}$ \\
\hline $90^{\text {th }}$ & 2.16 & 1.52 & 1.12 & 0.85 & 0.74 & $-0.961^{\star *}$ \\
\hline $120^{\text {th }}$ & 2.87 & 1.94 & 1.25 & 1.00 & 0.76 & $-0.957^{\star *}$ \\
\hline Correlations $(r)$ & $0.950^{*}$ & $0.952^{\star}$ & $0.942^{*}$ & $0.940^{*}$ & 0.884 & - \\
\hline $\mathrm{Ni}$ & $0 \%$ & $2.5 \%$ & $5 \%$ & $7.5 \%$ & $10 \%$ & Correlations $(r)$ \\
\hline $30^{\text {th }}$ & 2.37 & 1.29 & 1.24 & 0.56 & 0.48 & $-0.939^{* *}$ \\
\hline $60^{\text {th }}$ & 2.38 & 1.39 & 1.32 & 0.58 & 0.65 & $-0.930^{\star}$ \\
\hline $90^{\text {th }}$ & 2.43 & 1.40 & 1.43 & 0.66 & 0.66 & $-0.929^{*}$ \\
\hline $120^{\text {th }}$ & 2.29 & 1.53 & 1.54 & 0.72 & 0.67 & $-0.952^{\star *}$ \\
\hline Correlations $(r)$ & -0.423 & $0.957^{*}$ & $0.997^{* *}$ & $0.978^{\star}$ & 0.829 & - \\
\hline $\mathrm{Al}$ & $0 \%$ & $2.5 \%$ & $5 \%$ & $7.5 \%$ & $10 \%$ & Correlations $(r)$ \\
\hline $30^{\text {th }}$ & 0.95 & 0.72 & 0.74 & 0.65 & 0.71 & -0.759 \\
\hline $60^{\text {th }}$ & 1.07 & 0.77 & 1.06 & 1.09 & 1.26 & 0.627 \\
\hline $90^{\text {th }}$ & 1.15 & 0.99 & 1.42 & 1.16 & 1.33 & 0.499 \\
\hline $120^{\text {th }}$ & 1.18 & 1.25 & 1.36 & 1.15 & 1.36 & 0.418 \\
\hline Correlations $(r)$ & $0.967^{*}$ & $0.966^{*}$ & $0.917^{*}$ & 0.832 & 0.852 & - \\
\hline $\mathrm{Cr}$ & $0 \%$ & $2.5 \%$ & $5 \%$ & $7.5 \%$ & $10 \%$ & Correlations $(r)$ \\
\hline $30^{\text {th }}$ & 0.41 & 0.41 & 0.37 & 0.41 & 0.34 & -0.693 \\
\hline $60^{\text {th }}$ & 0.47 & 0.50 & 0.44 & 0.44 & 0.43 & -0.768 \\
\hline $90^{\text {th }}$ & 0.47 & 0.52 & 0.48 & 0.48 & 0.47 & -0.305 \\
\hline $120^{\text {th }}$ & 0.45 & 0.57 & 0.49 & 0.48 & 0.49 & -0.036 \\
\hline Correlations $(r)$ & 0.548 & $0.966^{*}$ & $0.948^{*}$ & $0.948^{*}$ & $0.951^{*}$ & - \\
\hline $\mathrm{Ga}$ & $0 \%$ & $2.5 \%$ & $5 \%$ & $7.5 \%$ & $10 \%$ & Correlations $(r)$ \\
\hline $30^{\text {th }}$ & 0.83 & 0.79 & 0.64 & 0.60 & 0.57 & $-0.962^{\star *}$ \\
\hline $60^{\text {th }}$ & 0.85 & 0.80 & 0.63 & 0.57 & 0.56 & $-0.953^{* *}$ \\
\hline $90^{\text {th }}$ & 0.86 & 0.82 & 0.63 & 0.61 & 0.57 & $-0.945^{\star *}$ \\
\hline $120^{\text {th }}$ & 0.85 & 0.80 & 0.64 & 0.60 & 0.56 & $-0.966^{\star *}$ \\
\hline Correlations $(r)$ & 0.718 & 0.513 & 0.000 & 0.298 & -0.447 & - \\
\hline $\mathrm{Pb}$ & $0 \%$ & $2.5 \%$ & $5 \%$ & $7.5 \%$ & $10 \%$ & Correlations $(r)$ \\
\hline $30^{\text {th }}$ & 0.05 & 0.06 & 0.05 & 0.05 & 0.05 & -0.354 \\
\hline $60^{\text {th }}$ & 0.11 & 0.13 & 0.12 & 0.11 & 0.06 & -0.702 \\
\hline $90^{\text {th }}$ & 0.12 & 0.13 & 0.11 & 0.11 & 0.11 & -0.707 \\
\hline $120^{\text {th }}$ & 0.14 & 0.14 & 0.14 & 0.13 & 0.13 & $-0.866^{\star}$ \\
\hline Correlations $(r)$ & $0.933^{*}$ & 0.838 & 0.867 & 0.894 & $0.969^{*}$ & - \\
\hline $\mathrm{Cu}$ & $0 \%$ & $2.5 \%$ & $5 \%$ & $7.5 \%$ & $10 \%$ & Correlations $(r)$ \\
\hline $30^{\text {th }}$ & 0.39 & 0.28 & 0.25 & 0.22 & 0.18 & $-0.954^{\star *}$ \\
\hline $60^{\text {th }}$ & 0.63 & 0.49 & 0.48 & 0.45 & 0.34 & $-0.945^{\star *}$ \\
\hline
\end{tabular}


Continued

\begin{tabular}{|c|c|c|c|c|c|c|}
\hline $90^{\text {th }}$ & 0.76 & 0.45 & 0.44 & 0.49 & 0.47 & -0.635 \\
\hline $120^{\text {th }}$ & 0.72 & 0.56 & 0.56 & 0.58 & 0.54 & -0.737 \\
\hline Correlations $(r)$ & 0.872 & 0.868 & 0.874 & $0.943^{*}$ & $0.986^{* *}$ & - \\
\hline In & $0 \%$ & $2.5 \%$ & $5 \%$ & $7.5 \%$ & $10 \%$ & Correlations $(r)$ \\
\hline $30^{\text {th }}$ & 7.33 & 3.92 & 3.46 & 3.59 & 2.71 & $-0.839^{*}$ \\
\hline $60^{\text {th }}$ & 7.62 & 4.52 & 3.77 & 3.90 & 3.29 & $-0.846^{*}$ \\
\hline $90^{\text {th }}$ & 8.31 & 4.22 & 4.08 & 4.15 & 3.31 & -0.801 \\
\hline $120^{\text {th }}$ & 8.43 & 4.49 & 4.49 & 4.75 & 3.80 & -0.772 \\
\hline Correlations $(r)$ & $0.968^{*}$ & 0.651 & $0.997^{\star \star}$ & $0.979^{*}$ & $0.953^{*}$ & - \\
\hline
\end{tabular}

${ }^{*} p<0.05 ;{ }^{* *} p<0.01$.

and $131.65 \mathrm{mg} / \mathrm{kg}$, respectively (Table 3). Plants grown on soils with low $\mathrm{Zn}$ concentrations therefore had higher BFs because of the lower Zn background concentration. Efroymson [35] reported that plants could tolerate a maximum $\mathrm{Zn}$ concentration of $50 \mathrm{mg} / \mathrm{kg}$ in the soil. Another study showed that the biomass of soybean decreased by $30 \%$ when grown on the soil with high $\mathrm{Zn}$ concentrations $(131 \mathrm{mg} / \mathrm{kg}, \mathrm{pH}=5.5)$, but the decrease in biomass was insignificant when the $\mathrm{Zn}$ concentration in the soil was diluted to $115 \mathrm{mg} / \mathrm{kg}$ [36] [37]. As in other studies, the high $\mathrm{Zn}$ concentration in the soil limited the uptake of $\mathrm{Zn}$ by plant roots [36] [37].

In the commercial soil treated with $10 \%$ CIGS TFSP, the concentration and $\mathrm{BF}$ of $\mathrm{Ni}$ in plants were only $40.48 \mathrm{mg} / \mathrm{kg}$ and 0.30 , respectively (Figure 1 (b) and Table 4), indicating that more than $70 \%$ of the $\mathrm{Ni}$ was retained in the commercial soil. The concentration of Ni in the Mollisol treated with 10\% of CIGS TFSP was approximately $13 \mathrm{mg} / \mathrm{kg}$ (Table 3), while $\mathrm{Ni}$ was about $9 \mathrm{mg} / \mathrm{kg}$ (Figure 2(b)) in the plants grown on it, with a BF of 0.67. Efroymson [35] reported that $\mathrm{Ni}$ in soil was toxic when the concentrations exceeded $30 \mathrm{mg} / \mathrm{kg}$. The concentration of $\mathrm{Ni}$ in commercial soil was most likely toxic to plant roots (Table 3), therefore less $\mathrm{Ni}$ was taken up from the commercial soil than from the Mollisol, which is consistent with other studies [37].

We also considered bioaccumulation of metals in vegetables regarding to food safety. The Al concentrations in vegetables grown on the Mollisol were usually higher than those in the commercial soil. We found that the $\mathrm{BFs}$ of $\mathrm{Al}$ in vegetables cultivated in Mollisol remained almost the same when treated with CIGS TPSP between 0 and 10\% (Table 5), indicating a potential for further $\mathrm{Al}$ bioaccumulation as $\mathrm{BFs}$ of $\mathrm{Al}$ were greater than 1 between 1.15 and 1.36. Similar trends were observed for other metals, for example, the $\mathrm{Cu}$ BFs ranged between 0.72 and 0.54 while the $\mathrm{Cu}$ concentrations varied between 13.54 and $20.38 \mathrm{mg} / \mathrm{kg}$ from the blank soil to the soil treated with $10 \%$ of CIGS TFSP. This indicated that In and Cu bioaccumulation may level off when metal concentrations reach a certain threshold concentration in the soil.

By referring the BFs higher than 1, bioaccumulation of $\mathrm{Zn}, \mathrm{Ni}$, In and $\mathrm{Al}$ in 
the plants grown on the Mollisol was evident. Of these metals, In revealed the most variable and greatest $\mathrm{BF}$ and was the metal that accumulated most in $\mathrm{Veg}_{\text {Brassica. }}$ Similar with commercial soil, the uptake of In in $\mathrm{Veg}_{\text {Brassica }}$ increased and varied with cultivation time and the concentrations of In in Mollisol. The BF of In was lower, but the In concentration was higher in vegetables cultivated in Mollisol treated with $10 \%$ of CIGS TFSP (BF 3.8, $13.72 \mathrm{mg} / \mathrm{kg}$ ) than in the Mollisol with no CIGS TFSP added (BF 8.43, $11.89 \mathrm{mg} / \mathrm{kg}$ ) after 120 days of cultivation (Table 5 and Figure 2(d)). It was clear that the In concentration was higher in vegetable tissues than in the soil for all the treatments of Mollisol (Table 3 and Figure 2(d)). This good ability on In accumulation was probably influenced by the selectivity and affinity of plant root systems when grown in Mollisol. Aluminum was ranked second with a BF of approximately 1.2 for all the treatments. The BFs of $\mathrm{Zn}$ and $\mathrm{Ni}$ were high in the treatments with low percentages of CIGS TFSP, but the values decreased to 1 or less when either $7.5 \%$ or $10 \%$ of CIGS TFSP were added and cultivated for 120 days. The concentrations of Ga, $\mathrm{Zn}, \mathrm{Pb}, \mathrm{Cu}, \mathrm{Ni}$ and $\mathrm{Cr}$ were generally lower in the vegetables than in the Mollisol treated with 10\% CIGS TFSP, which may reflect the lower uptake rates of these metals by plant grown in this soil (Table 3 and Table 5). However, a toxic effect due to high background concentrations of $\mathrm{Zn}$ in the Mollisol cannot be excluded, since the leaves of vegetables grown on the Mollisol were smaller and slightly chlorotic than those of the vegetables grown on the commercial soil.

\section{Oxisol}

Most of the vegetables cultivated in the Oxisol survived for less than 30 days, so we were unable to collect a complete data set for this soil. The $\mathrm{Veg}_{\text {Brassica }}$ grown in the contaminated Oxisol germinated but died after a short period of time. It survived longer in the blank samples of Oxisol than in the Oxisols to which different amounts of CIGS TFSP were added. This was because the low $\mathrm{pH}$ of this soil and the high metal concentrations increased metal availability and mobilization in enhancing the toxicity effects on vegetables. For example, the concentration of $\mathrm{Cu}$ in the Oxisol samples exceeded the maximum tolerate level of plants (level II, farmland, $\mathrm{pH}<6.5$ ) outlined in the Environmental Quality Standards for Soil ((Cu, $50 \mathrm{mg} / \mathrm{kg})$ GB 15618-1995, National standard, China).

\section{Conclusion}

In this study, we found that metal pollutants could be released from CIGS TFSP buried in soils under natural conditions. Zinc, $\mathrm{Ni}, \mathrm{Al}, \mathrm{Cr}, \mathrm{Ga}, \mathrm{Pb}, \mathrm{Cu}$ and In were released from CIGS TFSP in 3 different soils after 60 days of burial. The released metals could be bioaccumulated by Brassica parachinensis L. H. Bariley. Over a growth period of 120 days, vegetables survived in the commercial soil and the Mollisol but those grown in the Oxisol died because of a very acidic environment and the increasing toxicity contributed by the metals both from a high background content and released from CIGS TFSP. A high concentration of $\mathrm{Zn}$ (BF 3.6, $296 \mathrm{mg} / \mathrm{kg}$ ) was detected at $\mathrm{Veg}_{\text {Brassica }}$ grown in the commercial soil with 
$10 \%$ of CIGS TFSP added, while In (BF 3.8, $13.72 \mathrm{mg} / \mathrm{kg}$ ) was the most accumulated metal in $\mathrm{Veg}_{\text {Brassica }}$ grown in the Mollisol. There may be considerable adsorption of the metals released from CIGS TFSP by Veg $_{\text {Brassica }}$ even if the adsorption patterns may vary, depending on the selectivity and affinity of plants to metal ions in the soil as well as on the soil properties. Our results suggest that the inappropriate disposal of decommissioned CIGS TFSP will result in soil contamination, and the released contaminants will be then transferred to plants. We found that, as reported by Monier and Hestin [21] and Luo [22], Zn, Ni, Al, $\mathrm{Cr}, \mathrm{Ga}, \mathrm{Pb}, \mathrm{Cu}$ and $\mathrm{In}$ were released from CIGS TFSP. The thin-film layer of CIGS contains non-cadmium material and seemed to be much more environmentally friendly than the CdTe thin-film solar panels, but we observed the release of metals other than $\mathrm{Cd}$ from the damaged parts of thin-film layers during burial. We suggest that the thin-film solar panels should be recycled or rendered harmless during the EoL treatment, by collecting the reusable materials from decommissioned panels. In addition, we also suggest that newly-produced CIGS TFSPs should include a label that states the constituents of CIGS TFSP. Such a standard labeling plan will be a significant contribution to the EoL treatment of CIGS TFSPs, and should be a legal requirement worldwide.

\section{Acknowledgements}

We are grateful to the Beijing Normal University-Hong Kong University United International College and the Zhuhai Municipal Key Laboratory-Agricultural Product Quality and Food Safety for their financial supports of this research through research grants (R201625 and R1053).

\section{Conflicts of Interest}

The authors declare no conflicts of interest regarding the publication of this paper.

\section{References}

[1] Ha, N.N., Agusa, T., Ramu, K., Tu, N.P.C., Murata, S., Bulbule, K.A., Parthasaraty, P., Takahashi, S., Subramanium, A. and Tanabe, S. (2009) Contamination by Trace Elements at E-Waste Recycling Sites in Bangalore, India. Chemosphere, 76, 9-15. https://doi.org/10.1016/j.chemosphere.2009.02.056

[2] Ricard, M. (2012) Soil, Heavy Metals, and Human Health. In. Brevik, E.C. and Burgess, L.C., Eds., Soils and Human Health, CRC Press, Boca Raton, FL, 59-82.

[3] Radojevic, M. and Bashkin, V.N. (2007) Practical Environmental Analysis. 2nd Edition, RSC Publishing, Thomas Graham House, Cambridge, 312-316.

[4] Zhu, Y., Yu, H., Wang, J.L., Fang, W., Yuan, J.G. and Yang, Z. (2007) Heavy Metal Accumulations of 24 Asparagus Bean Cultivars Grown in Soil Contaminated with Cadmium Alone and with Multiple Metals (Cadmium, Lead and Zinc). Journal of Agricultural and Food Chemistry, 55, 1045-1052. https://doi.org/10.1021/jf062971p

[5] Tan, W.-N., Li, Z.-A., Qiu, J., Zou, B., Li, N.-Y., Zhuang, P., et al. (2011) Lime and 
Phosphate Could Reduce Cadmium Uptake by Five Vegetables Commonly Grown in South China. Pedosphere, 21, 223-229. https://doi.org/10.1016/s1002-0160(11)60121-5

[6] Hough, R.L., Breward, N., Young, S.D., Crout, N.M.J., Tye, A.M., Moir, A.M. and Thornton, I. (2004) Assessing Potential Risk of Heavy Metal Exposure from Consumption of Home-Produced Vegetables by Urban Populations. Environmental Health Perspectives, 112, 215-221. https://doi.org/10.1289/ehp.5589

[7] Cobb, G.P., Sands, K., Waters, M., Wixson, B.G. and Dorward-King, E. (2000) Accumulation of Heavy Metals by Vegetables Grown in Mine Wastes. Environmental Toxicological Chemistry, 19, 600-607. https://doi.org/10.1002/etc.5620190311

[8] Trumbo, P.A., Yates, A.A., Schlicker, S. and Poos, M. (2001) Dietary Reference Intakes: Vitamin A, Vitamin K, Arsenic, Boron, Chromium, Copper, Iodine, Iron, Manganese, Molybdenum, Nickel, Silicon, Vanadium, and Zinc. Journal of the Academy of Nutrition and Dietetics, 101, 294-301. https://doi.org/10.1016/S0002-8223(01)00078-5

[9] Prasad, A.S. (2003) Zinc Deficiency: Has Been Known of for 40 Years but Ignored by Global Health Organisations. British Medical Journal, 326, 409-410. https://doi.org/10.1136/bmj.326.7386.409

[10] Kabata-Pendias, A. and Mukherjee, A.B. (2007) Trace Elements from Soil to Human. Springer-Verlag, New York. https://doi.org/10.1007/978-3-540-32714-1

[11] Hambidge, K.M. and Krebs, N.F. (2007) Zinc Deficiency: A Special Challenge. Journal of Nutrition, 137, 1101-1105. https://doi.org/10.1093/jn/137.4.1101

[12] Denkhaus, E. and Salnikow, K. (2002) Nickel Essentiality, Toxicity, and Carcinogenicity. Critical Reviews in Oncology/Hematology, 42, 35-56. https://doi.org/10.1016/S1040-8428(01)00214-1

[13] Lee, T.D. and Ebong, A.U. (2017) A Review of Thin Film Solar Cell Technologies and Challenges. Renewable and Sustainable Energy Reviews, 70, 1286-1297. https://doi.org/10.1016/j.rser.2016.12.028

[14] Farkas, A. (1993) Preparation of Samples for Heavy Metal Analyses and Measuring Heavy Metals. Limnological Bases of Lake Management. Proceedings of the ILEC/UNEP International Training Course, 24, 160-163.

[15] McDonald, N.C. and Pearce, J.M. (2010) Producer Responsibility and Recycling Solar Photovoltaic Modules. Energy Policy, 38, 7041-7047. https://doi.org/10.1016/j.enpol.2010.07.023

[16] Corcelli, F., Ripa, M. and Ulgiati, S. (2017) End-of-Life Treatment of Crystalline Silicon Photovoltaic Panels. An Energy-Based Case Study. Journal of Cleaner Production, 161, 1129-1142. https://doi.org/10.1016/j.jclepro.2017.05.031

[17] Choi, J.K. and Fthenakis, V. (2014) Crystalline Silicon Photovoltaic Recycling Planning: Macro and Micro Perspectives. Journal of Cleaner Production, 66, 443-449. https://doi.org/10.1016/j.jclepro.2013.11.022

[18] Corcelli, F., Ripa, M., Leccisi, E., Cigolotti, V., Fiandra, V., Graditi, G., Ulgiati, S., et al. (2018) Sustainable Urban Electricity Supply Chain-Indicators of Material Recovery and Energy Savings from Crystalline Silicon Photovoltaic Panels End-of-Life. Ecological Indicators, 94, 37-51. https://doi.org/10.1016/j.ecolind.2016.03.028

[19] Sica, D., Malandrino, O., Supino, S., Testa, M. and Lucchetti, M.C. (2018) Management of End-of-Life Photovoltaic Panels as a Step towards a Circular Economy. Renewable and Sustainable Energy Reviews, 82, 2934-2945.

https://doi.org/10.1016/j.rser.2017.10.039

[20] Tammaro, M., Salluzzo, A., Rimauro, J., Schiavo, S. and Manzo, S. (2016) Experi- 
mental Investigation to Evaluate the Potential Environmental Hazards of Photovoltaic Panels. Journal of Hazardous Materials, 306, 395-405. https://doi.org/10.1016/j.jhazmat.2015.12.018

[21] Monier, V. and Hestin, M. (2011) Study on Photovoltaic Panels Supplementing the Impact Assessment for a Recast of the WEEE Directive. Final Report.

[22] Luo, C.L., Liu, C.P., Wang, Y., Liu, X., Li, F.B., Zhang, G. and Li, X.D. (2011) Heavy Metal Contamination in Soils and Vegetables near an e-Waste Processing Site, South China. Journal of Hazardous Materials, 186, 481-490. https://doi.org/10.1016/j.jhazmat.2010.11.024

[23] Gee, G.W. and Bauder, J.W. (1986) Particle Size Analysis. In: Klute, A., Ed., Methods of Soil Analysis, Part 1, Physical and Mineralogical Methods, ASA and SSSA, Madison, 383-411.

[24] Li, Z., Zhu, Y. and Wang, J. (1998) Some Physical and Chemical Characteristics of Sediment in West Lake, Hangzhou. Journal of Lake Sciences, 10, 79-84. https://doi.org/10.18307/1998.0113

[25] John, B. (2004) A Comparison of Two Methods for Estimating the Organic Matter Content of Sediments. Journal of Paleolimnology, 31, 125-127. https://doi.org/10.1023/B:JOPL.0000013354.67645.df

[26] Zhu, G.W., Qin, B.Q., Gao, G., Zhang, L. and Luo, L.C. (2004) Effects of Ignition on Determination of Loss on Ignition, Iron and Phosphorus in Sediments. Chinese Journal of Analysis Laboratory, 8, 72-76.

[27] Krishnamurty, K.V., Shpirt, E. and Reddy, M.M. (1976) Trace Metal Extraction of Soils and Sediments by Nitric Acid-Hydrogen Peroxide. Atomic Absorption Newsletter, 15, 68 .

[28] Li, X., Poon, C.S. and Liu, P.S. (2001) Heavy Metal Contamination of Urban Soils and Street Dusts in Hong Kong. Applied Geochemistry, 16, 1361-1368. https://doi.org/10.1016/S0883-2927(01)00045-2

[29] Anderson, R.A. (1997) Chromium as an Essential Nutrient for Humans. Regulatory Toxicology and Pharmacology, 26, 35-41. https://doi.org/10.1006/rtph.1997.1136

[30] Bona, K.R., Love, S., Rhodes, N.R., McAdory, D., Sinha, S.H., Kern, N., Kent, J., Strickland, J., Wilson, A., Beaird, J., Ramage, J., Rasco, J.F. and Vincent, J.B. (2011) Chromium Is Not an Essential Trace Element for Mammals: Effects of a “Low-Chromium” Diet. JBIC Journal of Biological Inorganic Chemistry, 16, 381. https://doi.org/10.1007/s00775-010-0734-y

[31] Long, X., Yang, X.E. and Ni, W. (2002) Current Situation and Prospect on the Remediation of Soils Contaminated by Heavy Metals. The Journal of Applied Ecology, 13, 757-762.

[32] Yang, G. and Zhou, R. (1994) Further Observations on the Human Maximum Safe Dietary Selenium Intake in a Seleniferous Area of China. Journal of Trace Elements and Electrolytes in Health and Disease, 8, 159-165.

[33] Dahmani-Muller, H., Van Oort, F., Gelie, B. and Balabane, M. (2000) Strategies of Heavy Metal Uptake by Three Plant Species Growing near a Metal Smelter. Environmental Pollution, 109, 231-238. https://doi.org/10.1016/S0269-7491(99)00262-6

[34] Han, W.X., Xu, Y.M., Du, W., Tan, A.H. and Jiang, R.F. (2009) Stoichiometry of Multi-Elements in the Zinc-Cadmium Hyperaccumulator Thlaspi Caerulescens Grown Hydroponically under Different Zinc Concentrations Determined bv ICP-AES. Spectroscopy and Special Analysis, 29, 9.

[35] Efroymson, R.A., Will, M.E., Suter, G.W. and Wooten, A.C. (1997) Toxicological Benchmarks for Screening Contaminants of Potential Concern for Effects on Terre- 
strial Plants: 1997 Revision. Oak Ridge National Laboratory, US Department of Energy, Oak Ridge.

[36] Yang, Y., Jiang, R.F., Li, H.F., Wang, W. and Zheng, R.L. (2010) Effect of the Soil Bulk Density on the Root Morphology and Cadmium Uptake by Thlaspicaerulescens Grown on Cd-Contaminated Soil. Chinese Journal of Environmental Science, 31, 3043-3049.

[37] White, M.C., Decker, A.M. and Chaney, R.L. (1979) Differential Cultivar Tolerance in Soybean to Phytotoxic Levels of Soil Zn. I. Range of Cultivar Response. Agronomy Journal, 71, 121-126.

https://doi.org/10.2134/agronj1979.00021962007100010031x 